\title{
Nitrogen availability in an apple orchard with weed management
}

\author{
Gustavo Brunetto ${ }^{1^{*}}$ Bruno Salvador Oliveira ${ }^{2} \odot$ Vítor Gabriel Ambrosini $^{2}$ \\ Rafael da Rosa Couto ${ }^{2}$ (-) Paula Beatriz Sete ${ }^{2} \odot$ Elano dos Santos Junior ${ }^{2}$ \\ Arcângelo Loss $^{2}\left(\right.$ Lincon Oliveira Stefanello da Silva ${ }^{1}$ Luciano Colpo Gatiboni ${ }^{3}$
}

\begin{abstract}
${ }^{1}$ Departamento de Solos, Centro de Ciências Rurais (CCR), Universidade Federal de Santa Maria (UFSM), Avenida Roraima, 1000, Camobi, 97105-900, Santa Maria, RS, Brasil. E-mail: brunetto.gustavo@gmail.com. ${ }^{*}$ Corresponding author.

${ }^{2}$ Departamento de Engenharia Rural, Centro de Ciências Agrárias, Universidade Federal de Santa Catarina (UFSC), Florianópolis, SC, Brasil. ${ }^{3}$ Departamento de Ciência do Solo e Recursos Naturais, Centro de Ciências Agroveterinárias, Universidade do Estado de Santa Catarina (UDESC), Lages, SC, Brasil.
\end{abstract}

\begin{abstract}
Weed management in apple orchards (Malus domestica) can affect the leaching of nitrogen (N) in soil. The study aimed to evaluate the potential leaching of $N$ forms in soil of an apple orchard with different weed management treatments. The experiment was conducted in an apple orchard implanted in 2008. In October 2011, 80 plants were selected and the following treatments were implemented: no weed management (NM), desiccation of weeds on the tree row with herbicide use (DR) and mechanical mowing of weeds on the tree row (MR). Yield was evaluated in the 2011/2012, 2012/2013 and 2013/2014 crop seasons. In May 2012 porous cup lysimeters were installed in the NM, $\mathrm{DR}$ and MR treatments. In the solution collected at $0.20 \mathrm{~m}, \mathrm{NH}_{4}^{+}-\mathrm{N}$ and $\mathrm{NO}_{3}^{-} \mathrm{N}$ were analyzed sixteen times and mineral $\mathrm{N}$ concentration was calculated. The highest concentrations of $\mathrm{NO}_{3}^{-}-\mathrm{N}$ and mineral $\mathrm{N}$ occurred in soil solution with DR, which increases availability of the nutrient to apple trees, but also enhances the potential losses. Weed management and $N$ flow in the solution did not affect apple yield.
\end{abstract}

Key words: mineral $N$, nitrate, ammonia, Malus domestica.

Disponibilidade de nitrogênio em solo de pomares de macieira com manejo de plantas espontâneas

RESUMO: O manejo de plantas espontâneas em pomares de macieira (Malus domestica) pode afetar a lixiviação de nitrogênio ( $N$ ) do solo. $O$ trabalho objetivou avaliar a lixiviação de formas de $N$ em solo sob pomar de macieiras com diferentes manejos de plantas espontâneas. $O$ experimento foi conduzido em um pomar de macieira implantado em 2008. Em outubro de 2011, foram selecionadas 80 plantas e implantados os tratamentos: sem manejo das plantas espontâneas (SM); dessecamento das plantas espontâneas na linha de plantio com uso de herbicidas (DL) e roçada mecânica das plantas espontâneas na linha de plantio (RL). Nas safras 2011/2012, 2012/2013 e 2013/2014 foi avaliada a produtividade. Em maio de 2012 foram instalados lisímetros com cápsula porosa nos tratamentos SM, DL e RL; e na solução coletada a 0,20m em dezesseis épocas foram analisados $\mathrm{NH}_{4}^{+}-\mathrm{N}$ e $\mathrm{NO}_{3}^{-}-\mathrm{N}$, e calculado o teor de $\mathrm{N}$-mineral. Os maiores teores de $\mathrm{NO}_{3}^{-}-\mathrm{N}$ e mineral- $\mathrm{N}$ ocorreram na solução no solo com DL, o que aumenta a disponibilidade do nutriente às macieiras, mas também potencializa as perdas. O manejo de plantas espontâneas e o fluxo de $N$ na solução não afetaram a produtividade de maçã.

Palavras-chave: perda de $N$, nitrato, amônio, Malus domestica.

\section{INTRODUCTION}

In the state of Santa Catarina (SC) approximately 17,604 hectares are cultivated with apple trees (Malus domestica) with total yield of 613,828 tons, which accounts for $45 \%$ of the national production (GOULART JUNIOR, 2015). In most orchards species of weeds, such as white clover (Trifolium repens), red clover (Trifolium pratenses), bahiagrass (Paspalum notatum) and heal and draw (Chaptalia nutans) are desiccated on the tree row of apple trees. In the inter-row, weeds are generally mowed and the residue is deposited on the soil surface. Weed control on tree rows in orchards is performed to reduce competition for water and nutrients, especially nitrogen (N) (DALLA ROSA et al., 2009; NAVA, 2010; ATUCHA et al., 2011). In the event of competition for $\mathrm{N}$, it may adversely affect apple yield (PELIZZA et al., 2009; NAVA, 2010; ATUCHA et al., 2011).

Weed management in orchards, particularly those on the tree row, can lower $\mathrm{N}$ forms in the soil solution, especially nitrate $\left(\mathrm{NO}_{3}^{-}-\mathrm{N}\right)$ (VENTURA et al., 2008; GE et al., 2015; ZHANG at al., 2015; HAMMERMEISTER et al., 2016). This is because weeds can absorb $\mathrm{N}$ forms from the soil throughout the cycle incorporating them in the plant biomass and later during the process of decomposition release $\mathrm{N}$ onto the soil surface. (EISSENSTAT, 2007; ATUCHA et al., 2011; BRUNETTO et al., 2014; VENTURA et al., 2014; WANG et al., 2016). Consequently, N 
derived from the decomposition of weed residue may contribute to apple nutrition (TAGLIAVINI et al., 2007; SCANDELLARI et al., 2007).

In the southern region of Brazil there are few studies that relate weed management systems in apple orchards with $\mathrm{N}$ concentration in the soil solution which is associated with nutrient availability to plants, but also to nutrient loss. Therefore, this study aimed to evaluate the concentration of $\mathrm{N}$ forms in soil of an apple orchard with different weed management treatments.

\section{MATERIALS AND METHODS}

The experiment was conducted in an apple orchard implanted in 2008 in the city of Urubici, located in the Planalto Serrano region of the state of Santa Catarina, southern Brazil (28 02'47.5'S $49^{\circ} 26^{\prime} 26.6^{\prime \prime} \mathrm{W}, 1000 \mathrm{~m}$ altitude). According to the Köppen classification the climate is Cfb with the average annual rainfall varying between 1360$1600 \mathrm{~mm}$. The average maximum and minimum temperatures vary from 19.4 to $22.3^{\circ} \mathrm{C}$ and 9.2 to $10.8^{\circ} \mathrm{C}$, respectively (Figure 1 ). The temperatures below or equal to $7.2{ }^{\circ} \mathrm{C}$ or ranged from 642 to 847 hours accumulated annually.
The soil was classified as Haplumbrept soil (SOIL SURVEY STAFF, 2006). It presented the following attributes before the experiment, at $0.0-0.20 \mathrm{~m}$ top-layer: medium texture with $475 \mathrm{~g}$ $\mathrm{kg}^{-1}$ sand, $294 \mathrm{~g} \mathrm{~kg}^{-1}$ silt and $231 \mathrm{~g} \mathrm{~kg}^{-1}$ clay; $46 \mathrm{~g} \mathrm{~kg}^{-1}$ organic matter; $5.8 \mathrm{pH}$ in water (1: 1); $0.0 \mathrm{cmol}_{\mathrm{c}} \mathrm{dm}^{-3}$ exchangeable $\mathrm{Al}, 8.45 \mathrm{cmol}_{\mathrm{c}} \mathrm{dm}^{-3}$ exchangeable $\mathrm{Ca}$ and $3.15 \mathrm{cmol} \mathrm{dm}^{-3}$ exchangeable $\mathrm{Mg}$ (both extracted by $\mathrm{KCl} 1 \mathrm{~mol} \mathrm{~L}^{-1}$ ); $32.1 \mathrm{mg} \mathrm{dm}^{-3}$ available $\mathrm{P}$ and $243 \mathrm{mg}$ $\mathrm{dm}^{-3}$ exchangeable $\mathrm{K}$ (both extracted by Mehlich-1), $12.22 \mathrm{mg} \mathrm{dm}^{-3} \mathrm{CEC}_{\text {effective }}, 16.38 \mathrm{mg} \mathrm{dm}^{-3} \mathrm{CEC}_{\mathrm{pH} 7.0}$ and $74.6 \%$ base saturation.

The orchard had two commercial varieties: Gala and Fuji, which comprised $70 \%$ and $30 \%$ of the plants, respectively. The cultivar Fuji was used as pollinator, and only plants of the cultivar Gala were selected for the experiment. The orchard was conducted with central leader system and the plants were grafted on Marubakaido rootstock with a $20 \mathrm{~cm}$ filter of M9. Plant density was of 1,482 plants ha ${ }^{-1}(4.5 \mathrm{~m}$ between rows and $1.5 \mathrm{~m}$ between plants on the row).

In October 2011, we selected 80 plants according to a complete randomized block experimental design, with four replications. Five plants were marked in each repetition and the three central plants were evaluated. The following treatments were

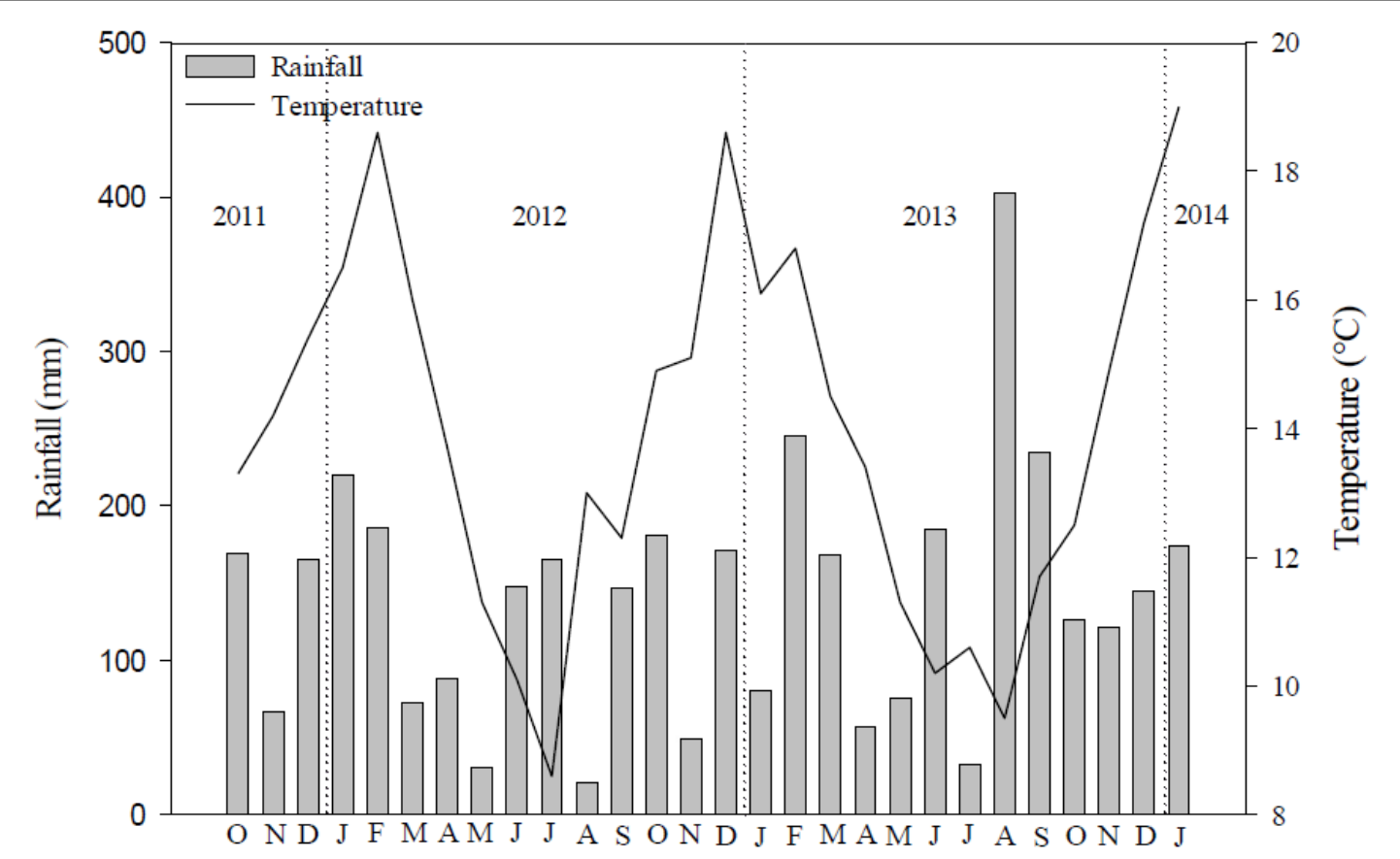

Figure 1 - Average rainfall $(\mathrm{mm})$ and air temperature $\left({ }^{\circ} \mathrm{C}\right)$ during the experiment. 
implemented: no weed management (NM), desiccation of weeds on the tree row (DR) and mowing of the weeds on the tree row of apple trees (MR).

Mowing and herbicide application were done when the plants were approximately $30 \mathrm{~cm}$ height. Eight non-residual herbicide applications with the active ingredient glyphosate and twelve mowings were done during the experiment. Mowings of the plants were done at approximately $10 \mathrm{~cm}$ from the soil surface, and a dosage of $50 \mathrm{~mL}$ of the product was used for every $20 \mathrm{~L}$ of water in each desiccation, with a spray volume of approximately $300 \mathrm{~L} \mathrm{ha}^{-1}$. In the orchard there were predominantly weeds of white clover (Trifolium repens), red clover (Trifolium grass cultivation), bahiagrass (Paspalum notatum) and chaptalia (Chaptalia nutans). Annually, 50kg $\mathrm{P}_{2} \mathrm{O}_{5}$ $\mathrm{ha}^{-1}$ (triple superphosphate) and $200 \mathrm{~kg} \mathrm{~K}_{2} \mathrm{O} \mathrm{ha}^{-1}(\mathrm{KCl})$ were top dressing applied and without incorporation.

In the 2011/2012, 2012/2013 and 2013/2014 crops, all the fruits of the plants were collected and weighed. In May 2012 porous cup lysimeters were installed in the three treatments: NM, DR and MR. Lysimeters were installed on the crop row at a $0.20 \mathrm{~m}$ depth in three experimental units of each of the treatments. For the installation of the lysimeters, drilling in the soil was done with the help of a Dutch auger to a depth of $0.20 \mathrm{~m}$ and soon were placed after the lysimeters. Afterwards, part of the removed soil was put back for the fixing of the lysimeters, carefully adding the corresponding soil to each depth. Additionally, after the fixing of the lysimeters, an expansive material (vermiculite) was added to the $0.05 \mathrm{~m}$ depth to avoid preferential flow of water in the soil profile.

Collections of the soil solution were made on $06 / 07,07 / 11,09 / 15,10 / 10$ and $12 / 10$ of 2012 ; $01 / 22,05 / 15,07 / 12,08 / 14,09 / 11$ and $11 / 20$ of 2013 ; and $01 / 202014$. In order to do this, vacuum was applied to the lysimeters $(25 \mathrm{kgf})$, using a manual pump. The vacuum was held for approximately 24 hours. The solution was removed from inside the lysimeters with a syringe attached to a hose. Afterwards, the solution samples were stored in $90 \mathrm{~mL}$ snap-cap vials and kept in a polystyrene box with ice, until, $\mathrm{NH}_{4}^{+}-\mathrm{N}^{-}$and $\mathrm{NO}_{3}{ }_{-}^{-}$ -N determinations (TEDESCO et al., 1995).

The yield of apple trees was subjected to analysis of variance and when there was a significant effect, the means were compared by Tukey test $(\alpha=$ $5 \%$ ). Results of $\mathrm{N}$ in the soil solution throughout the period of evaluation, due to the lack of "independence" among the observations, made polynomial regression analysis unviable. In addition, inability to experimentally control environmental variables such as volume and interval of rainfall has implications as to the satisfaction of all the assumptions of analysis of variance. Thus, we chose to present the means of the results obtained with their respective standard deviations. The annual averages of the attributes $\mathrm{NH}_{4}^{+}-\mathrm{N}, \mathrm{NO}_{3}^{-}-\mathrm{N}$, mineral $\mathrm{N}$ and yield were submitted to principal component analysis (PCA).

\section{RESULTS AND DISCUSSION}

Ammonia $\left(\mathrm{NH}_{4}^{+}-\mathrm{N}\right)$ concentrations did not differ among the weed management treatments from June 2012 until September 2013 (Figure 2A). On average, $\mathrm{NH}_{4}^{+}-\mathrm{N}$ concentration in the soil solution did not exceed $1 \mathrm{mg} \mathrm{L}^{-1}$ in all the collections (median of 0.41 ; maximum and minimum concentration of 2.24 and $0.07 \mathrm{mg} \mathrm{L}^{-1}$, respectively). Low $\mathrm{NH}_{4}^{+}-\mathrm{N}$ concentrations in the soil solution can be attributed to the rapid transformation of $\mathrm{NH}_{4}^{+}-\mathrm{N}$ into $\mathrm{NO}_{2}^{-}-\mathrm{N}$ and subsequently into $\mathrm{NO}_{3}{ }^{-}-\mathrm{N}$ (WU et al,. 2014). However, on November 20 of 2013 and January 20 of 2014, the highest $\mathrm{NH}_{4}^{+}-\mathrm{N}$ concentrations were observed in the solution of the DR treatment. This probably occurred due to mineralization of soil organic $\mathrm{N}$, caused by the increase of air temperature (Figure 1) and consequently of soil temperature (ZHANG et al., 2006; BENBI et al., 2014). In the NM treatment there were always plants on the soil surface and, thus, the soil temperature may have decreased, consequently reducing the mineralization of organic matter and resulting in lower $\mathrm{NH}_{4}{ }^{+}-\mathrm{N}$ concentration (BENBI et al., 2014; LEON et al., 2015). Considering the sum of the twelve collections, there is a N-NH${ }_{4}^{+}$potential loss of $9.1 \mathrm{mg} \mathrm{L}^{-1}$ in the NM, DR and MR treatments, respectively. Therefore $\mathrm{NH}_{4}^{+}-\mathrm{N}$ concentration in DR was 2.8 and $11.3 \%$ higher than in the MR and NM treatments, respectively.

The highest concentrations of $\mathrm{NO}_{3}$ $-\mathrm{N}$ on June 7 were observed in the soil of the DR treatment (Figure 2B). On July 11 the highest $\mathrm{NO}_{3}^{-}-\mathrm{N}$ concentrations were also observed in this treatment, which did not differ from MR, but presented a difference from the NM treatment. On September $15, \mathrm{NO}_{3}-\mathrm{N}$ concentrations decreased in all treatments compared to the first two collections with values close to zero. In this collection, $\mathrm{NO}_{3}^{-}-\mathrm{N}$ concentrations were also higher in the DR treatment compared to the other weed management treatments. On October 10 and December 20 of 2012, concentrations of $\mathrm{NO}_{3}$ -N increased in all treatments compared to the third collection with the highest concentrations observed in the DR treatment and the smallest in the NM treatment (Figure 2B). In December 20 of 2012, the highest 


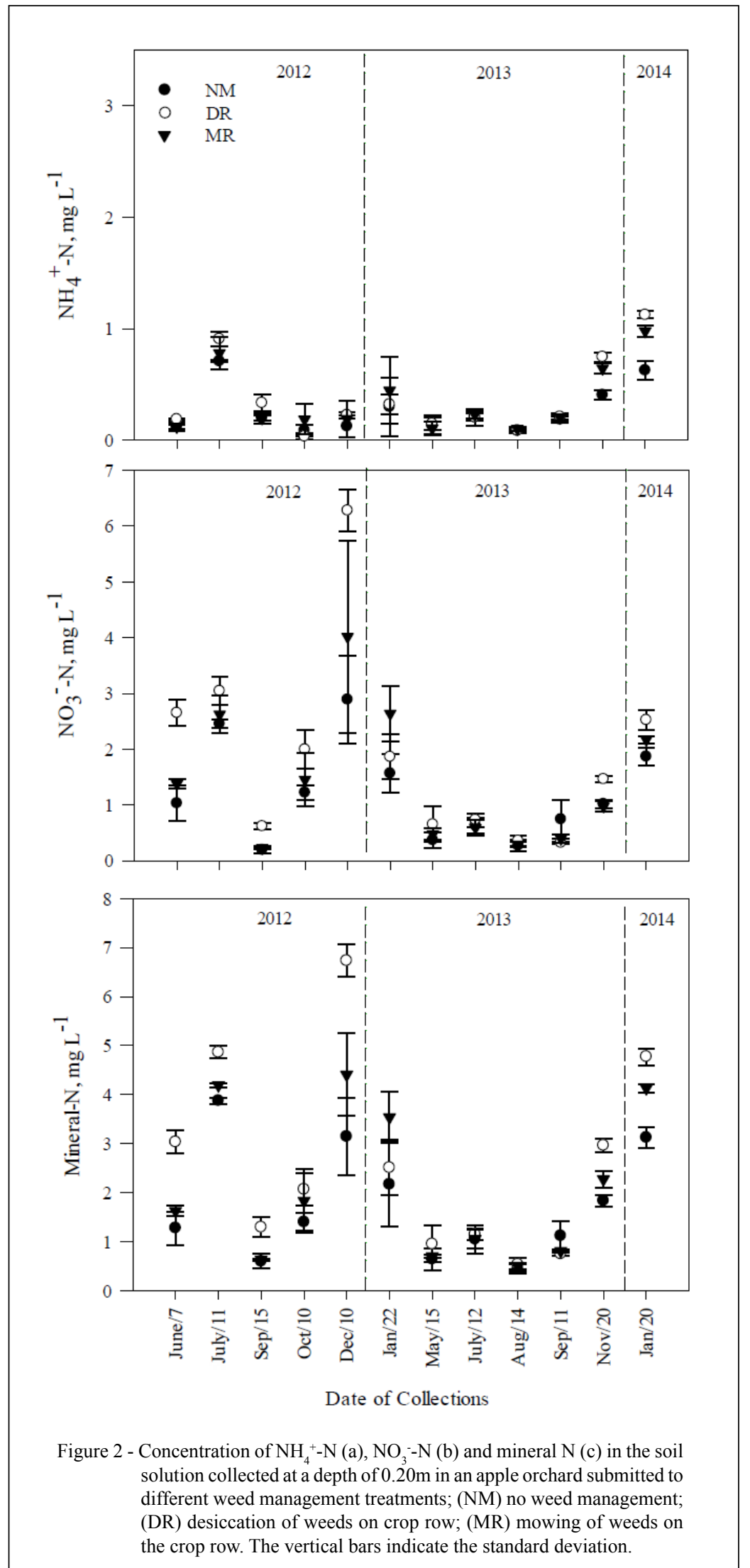

Ciência Rural, v.48, n.5, 2018. 
concentrations of $\mathrm{NO}_{3}^{-}-\mathrm{N}$ were observed in the DR treatment $\left(6.8 \mathrm{mg} \mathrm{L}^{-1}\right)$. However, this concentration is lower than the maximum concentration allowed for the potable use of groundwater, which is $10 \mathrm{mg} \mathrm{L}^{-1}$ for human consumption (BRAZIL, 2004).

On January 22, May 15, July 12, August 14 and September 11 of 2013, concentrations of $\mathrm{NO}_{3}-\mathrm{N}$ did not differ among treatments (Figure 2B). However, for the collections made on November 20 of 2013 and January 20 of 2014, the highest concentrations of $\mathrm{NO}_{3}^{-}-\mathrm{N}^{-}$in the soil solution were observed in the DR treatment. This is probably due to increased mineralization of soil organic matter, due to temperatures having reached their highest values during the period (Figure 1). Therefore, desiccation of weeds associated with the highest temperatures promoted a higher decomposition rate of plant residues; and consequently, there was greater release of $\mathrm{NO}_{3}^{-}-\mathrm{N}$ in the soil solution (LEON et al., 2015). Additionally, weed management in the DR treatment presented higher $\mathrm{NO}_{3}^{-}-\mathrm{N}$ concentration in the soil solution in seven of the 12 collections made in the experiment (Figure 2B). This probably happened because of the greatest availability of this $\mathrm{N}$ form in the soil which enhances leaching (VENTURA et al., 2008; BRUNETTO et al., 2011). Furthermore, when considering the sum of the twelve collections, the DR treatment presented $22.50 \mathrm{mg} \mathrm{L}^{-1} \mathrm{NO}_{3}^{-}-\mathrm{N}$. This concentration is $15.3 \%$ and $9.8 \%$ higher than those observed in the NM and MR treatments, respectively.

Mineral $\mathrm{N}$ and $\mathrm{NO}_{3}^{-}-\mathrm{N}$ concentrations showed the same pattern and in general the higher mineral $\mathrm{N}$ concentration was reported in DR compared to NM and MR treatments (Figure 2C). When there is the presence of weeds on the soil surface minor losses of $\mathrm{N}$ in the culture system may occur due to slower element cycling, mainly in the form of $\mathrm{NO}_{3}{ }^{-}$ $-\mathrm{N}$. Management with frequent mowing of weeds tends to stimulate the absorption and accumulation of a greater amount of $\mathrm{N}$ at its roots for the regrowth of the shoots after cutting; thereby, decreasing nutrient leaching in the soil which is dependent on the adsorption and the amount of the element in the soil solution (JANSSENS et al., 2010; BRUNETTO et al., 2011; LORENSINI et al., 2012). Thus, there is a decrease in $\mathrm{NO}_{3}^{-}-\mathrm{N}$ transfer in the soil deeper profile, as observed in this study. This is because the lowest $\mathrm{NO}_{3}^{-}-\mathrm{N}$ concentrations were reported in the soil solution of the MR and NM treatments (Figure 2B), which reflects directly the lowest concentration of mineral $\mathrm{N}$ in the solution (Figure 2C). Considering the sum of the twelve collections, there is $\mathrm{NH}_{4}^{+} \mathrm{-N}$ potential loss of $9.1 \mathrm{mg} \mathrm{L}^{-1}$ in the DR treatment.
Therefore, $\mathrm{t} \mathrm{NH}_{4}^{+}-\mathrm{N}$ concentration in the $\mathrm{MR}$ and $\mathrm{NM}$ treatments were 5.1 and $6 \%$ higher than in the DR treatment, respectively.

Using PCA, which included the variables $\mathrm{NH}_{4}^{+}-\mathrm{N}, \mathrm{NO}_{3}^{-}-\mathrm{N}$ and mineral $\mathrm{N}$ of the three treatments and of the three years of evaluation, it was found through the first principal component (Factor 1), which explained $63.85 \%$ of the data, that there was separation of the NM, DR, MR treatments in 2014 and DR in 2012 of the NM, DR, MR treatments in 2013, and NM and MR in 2012 (Figure 3). Variables that contributed most to this separation were $\mathrm{NH}_{4}^{+}-\mathrm{N}, \mathrm{NO}_{3}^{-}-\mathrm{N}$ and mineral $\mathrm{N}$. Despite the treatments presenting specific differences among them in the three years of evaluation, PCA has shown that when considering the annual average, behavior is quite homogeneous and the effects are seen from one year to the next. This fact can be explained by rainfall between August and September 2013, which represented $33 \%$ of the total amount of rainfall during the evaluation period. Therefore, $\mathrm{N}$ solution may have moved to the deeper layers. In addition, the increase in absorption and accumulation of $\mathrm{N}$ by the apple trees in the $2012 / 2013$ crop may have contributed to this effect, since fruit yield per plant in this period was $30 \%$ higher than the previous.

Principal component 2 explained $23.45 \%$ of the data and was influenced only by yield. Apple yield in the 2011/2012, 2012/2013 and 2013/2014 crops was not affected by weed management treatments in the apple orchard. In the 2011/2012 crop, apple yield was $14.3 ; 17.2$ and $13.8 \mathrm{Mg} \mathrm{ha}^{-1}(\mathrm{CV}=12.5 \%)$ in the NM, $\mathrm{DR}$ and $\mathrm{MR}$ management treatments, respectively. In the 2012/2013 crop, yield was 28.9; 31.0 and $35.7 \mathrm{Mg} \mathrm{ha}^{-1}(\mathrm{C} . \mathrm{V} .=13.1 \%)$ in the same management treatments, respectively. Conversely, in the 2013/2014 crop, it was $27.0 ; 29.1$ and $33.9 \mathrm{Mg} \mathrm{ha}^{-1}(\mathrm{C} . \mathrm{V} .=12.4 \%$ ), respectively. In the $2012 / 2013$ crop, apple fruit yield was higher than that observed in $2011 / 2012$, with an increase of $102 \%, 81 \%$ and $158 \%$ in NM, RD and MR management treatments, respectively. The increase in yield over the years may be attributed to increased number of productive buds and their differentiation (NAVA, 2010), with increase of the number of fruit per plant. But in the 2013/2014 crop, the average yield of the treatments was $5.5 \%$ lower than that observed in $2012 / 2013$. This was due since there were two frosts in October 2013 during the bud sprout and flowering of the apple trees, which caused the fall of the flowers and consequently resulted in a decrease in yield in all the treatments.

During the 19 months of the study, it was observed that as higher concentrations of $\mathrm{NO}_{3}^{-}-\mathrm{N}$ and; consequently, minerals $\mathrm{N}$ in the soil solution as 


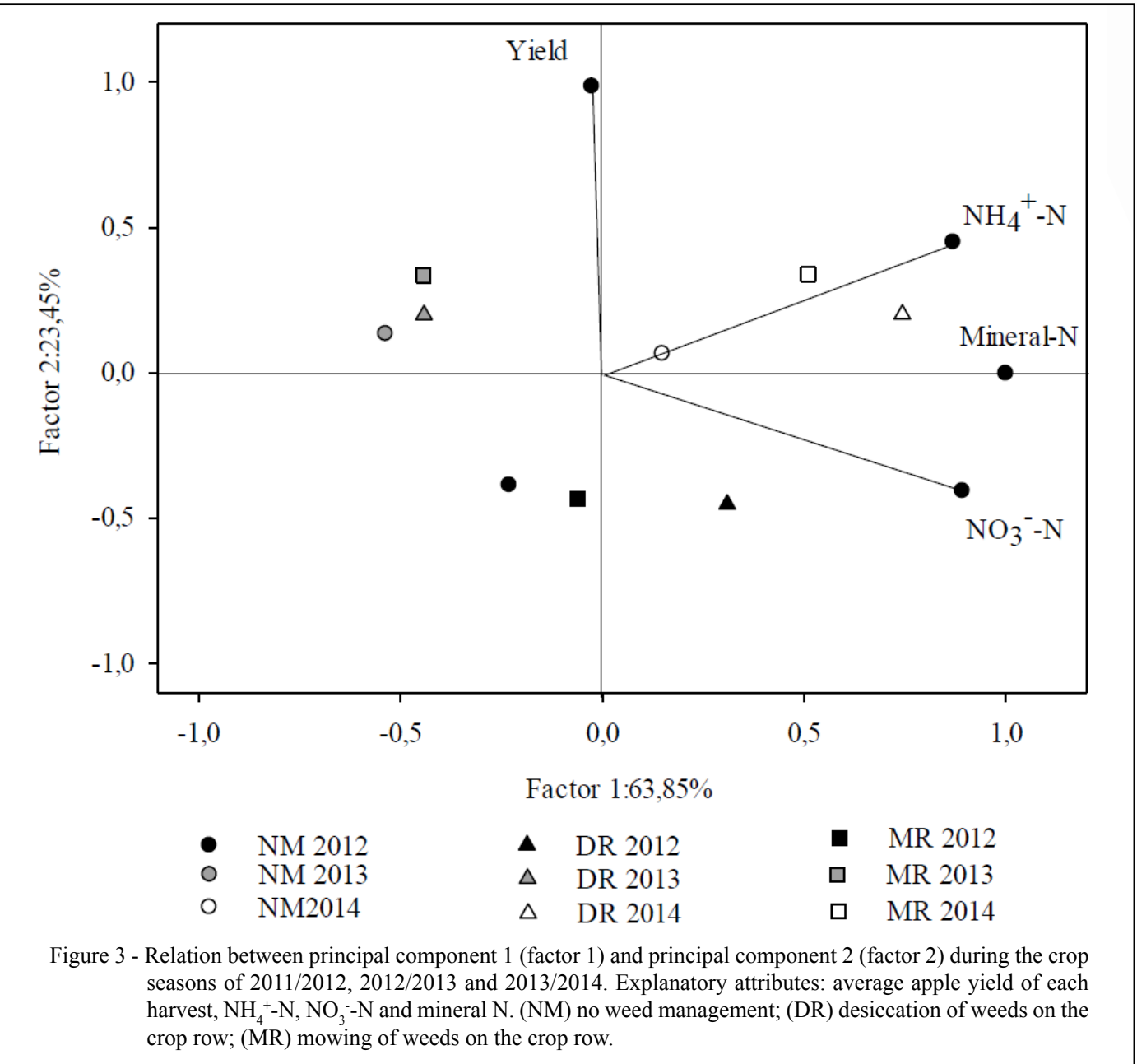

consequence of desiccation of weeds on the tree row. Thus, we recommended the use of species of cover plants between the lines of the orchards, which avoids as losses of $\mathrm{N}$ the system and reduces a contamination of subsurface waters.

\section{CONCLUSION}

The high concentration of minerals and $\mathrm{NO}_{3}^{-}-\mathrm{N}$ in soil solutions collected from application of herbicide plots increased the availability of nutrients to apple trees and $\mathrm{N}$ loss potential, but without effect on apple yield.

\section{ACKNOWLEDGEMENTS}

We would like to thank Conselho Nacional de Desenvolvimento Científico e Tecnológico (CNPq) for the research scholarship granted to the first author.

\section{DECLARATION OF CONFLICT OF INTEREST}

The authors declared no potential conflicts of interest with respect to the research, authorship, and/or publication of this article.

\section{REFERENCES}

ATUCHA, A. et al. Long-term effects of four groundcover management systems in an apple orchard. Hort Science, v.46, p.1176-1183, 2011. Available from: $<$ http://hortsci.ashspublications. org/content/46/8/1176.full.pdf+html $>$. Accessed: Nov. 10, 2016.

BENBI, D.K. et al. Decomposition of particulate organic matter is more sensitive to temperature than the mineral associated organic matter. Soil Biology \& Biochemistry, v.70, p.183-192, 2014. Available from: $<$ https:// www.sciencedirect.com/science/article/pii/S0038071713004768>. Accessed: Jan. 12, 2017. doi: 10.1016/j.soilbio.2013.12.032.

BRUNETTO, G. et al. Contribution of nitrogen from agricultural residues of rye to 'Niagara Rosada' grape nutrition. Scientia Horticulturae, v.169, p.66-70, 2014. Available from: <https:// 
www.sciencedirect.com/science/article/pii/S0304423814000922>. Accessed: Jan. 09, 2017. doi:10.1016/j.scienta.2014.02.019.

BRUNETTO, G. et al. Nutrients release during the decomposition of mowed perennial ryegrass and White clover and its contribution to nitrogen nutrition of grapevine. Nutrient Cycling in Agroecosystems, v.90, p.299-308, 2011. Available from: <https://link.springer.com/ article/10.1007/s10705-011-9430-8>. Accessed: Feb. 12, 2017. doi: $10.1007 / \mathrm{s} 10705-011-9430-8$.

DALLA ROSA, J. et al. Soil chemical properties and grapevine yield affected by cover crop management in Serra Gaucha, Southern Brazil. Revista Brasileira de Ciência do Solo, v.33, p.179-187, 2009. Available from: <http://www.scielo.br/pdf/rbcs/v33n1/19.pdf >. Accessed: Feb. 01, 2017. doi: 10.1590/S0100-06832009000100019.

EISSENSTAT, D.M. et al. Seasonal patterns of root growth in relation to shoot phenology in grape and apple. Acta Horticulturae, v.721, p.21-26, 2007. Available from: <https://www.actahort.org/ members/showpdf?booknrarnr=721_1>. Accessed: Jan. 15, 2017. doi: 10.17660/ActaHortic.2006.721.1.

HAMMERMEISTER, A.M. Organic weed management in perennial fruits. Scientia Horticulturae, v.208, p.28-42, 2016. Available from: <https:/www.sciencedirect.com/science/article/pii/ S0304423816300528>. Accessed: Feb. 15, 2017. doi: 10.1016/j. scienta.2016.02.004.

SOIL SURVEY STAFF. Soil taxonomy: A basic system of soil classification for making and interpreting soil surveys. Washington DC: US Government Printing Office, 2006.

GE, S. et al. Gross nitrification rates and nitrous oxide emissions in an apple orchard soil in northeast china. Pedosphere, v.25, p.622630, 2015. Available from: $<$ https://www.sciencedirect.com/science/ article/pii/S1002016015300424>. Accessed: Feb. 08, 2017. doi: 10.1016/S1002-0160(15)30042-4.

GOULART JUNIOR, R. Maçã: produção e mercado nacionais In: Síntese Anual da Agricultura de Santa Catarina 2014-2015. Florianópolis: Epagri, 2015. Anual. Continuação da Síntese informativa sobre a agricultura catarinense.

JANSSENS, I.A. et al. Reduction of forest soil respiration in response to nitrogen deposition. Nature Geoscience, v.3, p.315-322, 2010. Available from: <https://www.nature.com/articles/ngeo844> Accessed: Jan. 22, 2017. doi: 10.1038/ngeo844.

LEON, A. et al. Change in soil carbon in response to organic amendments in orchards and tea gardens in Japan. Geoderma, v.237, p.168-175, 2015. Available from: <https://www.sciencedirect.com/ science/article/pii/S0016706114003334>. Accessed: Feb. 10, 2017. doi: 10.1016/j.geoderma.2014.09.001.

LORENSINI, F. et al. Lixiviation and volatilization of nitrogen in Sandy Typic Hapludalf soil cultivated with grapevine submitted to the nitrogen fertilization. Ciência Rural, v.42, p.1173-1179, 2012. Available from: $<\mathrm{http}: /$ www.scielo.br/scielo.php?script $=$ sci_arttext \&pid $=$ S0103-84782012000700006 $>$. Accessed: Feb. 12, 2017. doi: 10.1590/S0103-84782012005000038.

NAVA, G. Organic fertilization and weed control effects on yield and growth of 'fuji' apple. Revista Brasileira de Fruticultura, v.32, p.1231-1237, 2010. Available from: <http://www.scielo.br/pdf/ rbf/v32n4/v32n4a34.pdf>. Accessed: Feb. 08, 2017. doi: 10.1590/ S0100-29452010000400034.

PELIZZA, T.R. et al. Soil coverage and apple tree growth on the establishment of an orchard under organic production system. Revista Brasileira de Fruticultura, v.21, p.739-748, 2009. Available from: $<$ http://www.scielo.br/scielo.php?script=sci arttext \&pid=S0100-29452009000300017>. Accessed: Feb. 10, 2017. doi: 10.1590/S0100-29452009000300017.

SCANDELLARI, F. et al. Assessing nitrogen fluxes from roots to soil associated to rhizodeposition by apple (Malus domestica) trees. Trees, v.21, p.499-505, 2007. Available from: $<$ https://link.springer. com/article/10.1007/s00468-007-0141-3>. Accessed: Feb. 10, 2017. doi: $10.1007 / \mathrm{s} 00468-007-0141-3$.

TAGLIAVINI, M. Nutrient recycling during the decomposition of apple leaves (Malus domestica) and mowed grasses in orchard. Agriculture Ecosystems Environment, v.118, p.191-200, 2007. Available from: $<$ https://www.sciencedirect.com/science/article/pii/ S0167880906001708>. Accessed: Feb. 08, 2017. doi: 10.1016/j. agee.2006.05.018.

TEDESCO, M.J. et al. Análise de solo, plantas e outros materiais. Porto Alegre: UFRGS, 1995, 174 p.

VENTURA, M. Nitrogen balance and losses through drainage waters in an agricultural watershed of the Po Valley (Italy). European Journal Agronomy, v.29, p.108-115, 2008. Available from: <https:// www.sciencedirect.com/science/article/pii/S1161030108000488>. Accessed: Feb. 11, 2017. doi: 10.1016/j.eja.2008.05.002.

VENTURA, M. et al. Effect of biochar addition on soil respiration partitioning and root dynamics in an apple orchard. European Journal of Soil Science, v.65, p.186-195, 2014. Available from: $<$ http://onlinelibrary.wiley.com/doi/10.1111/ejss.12095/abstract $>$. Accessed: Jan. 10, 2017. doi: 10.1111/ejss.12095.

WANG, N. et al. Towards sustainable intensification of apple production in China-Yield gaps and nutrient use efficiency in apple farming systems. Journal of Integrative Agriculture, v.14, p. 716-725, 2016. Available from: <https://www.sciencedirect.com/science/article/pii/ S2095311915610991>. Accessed: Feb. 11, 2017. doi: 10.1016/S20953119(15)61099-1.

WU, J. et al. Model predictive control of biological nitrogen removal via partial nitrification at low carbon/nitrogen $(\mathrm{C} / \mathrm{N})$ ratio. Journal of Environmental Chemical Engineering, v.30, p.1899-1906, 2014. Available from: <https://www.sciencedirect.com/science/article/pii/ S2213343714001730>. Accessed: Feb. 15, 2017. doi: 10.1016/j. jece.2014.08.007.

ZHANG, X.H. et al. Topsoil organic carbon mineralization and $\mathrm{CO}_{2}$ evolution of three paddy soils from south China and the temperature dependence. Journal of Environmental Sciences, v.19, p.319-326, 2006. Available from: $<$ https://www.sciencedirect.com/science/article/ pii/S1001074207600527>. Accessed: Feb. 08, 2017. doi: 10.1016/ S1001-0742(07)60052-7.

ZHANG, Y. et al. Effect of orchard age on soil nitrogen transformation in subtropical China and implications. Journal of Environmental Sciences, v. 34, p. 10-19, 2015. Available from: <https://www.ncbi. nlm.nih.gov/pubmed/26257341>. Accessed: Jan. 11, 2017. doi: 10.1016/j.jes.2015.03.005. 